\title{
OBITUARY
}

\section{PROFESSOR EMERITUS WALTER SIMON}

Walter Simon, Professor of Chinese in the University of London from 1947 to 1960 , died on 22 February 1981 at the age of 87 . The imprint which he left on sinology, on the School, and on wider learned circles here would have been remarkable in anybody. It was memorable in one who rebuilt his career in his forties, after the withdrawal of his licence to teach under the Nazi regime, in a country which then devoted but scanty resources to Oriental studies.

Simon, who had been an Extraordinarius in Berlin, became a Lecturer in the School in 1936, and was promoted Reader in 1938. During the 1939-45 war he was plunged into the training of interpreters and translators for the armed forces-on a scale we hardly emulate--and from this came a whole series of textbooks in the G.R. transcription, which served the needs of a generation. His chair came in time for him to preside, with discernment and devotion, over the Scarbrough expansion which fledged the School's Far East department as we have it today; and bore wider fruit as disciples moved on to establish these studies elsewhere.

He did not become inactive on retirement. Besides visiting professorships in the early years he edited Asia Major until its lamented demise, and was a diligent president of the Philological Society from 1967 to 1970.

It is particularly fitting that Simon be remembered in the pages of the Bulletin. His contributions cover more than forty years, from 'The reconstruction of Archaic Chinese', in BSOAS, Ix, 2, to 'Some Tibetan etymologies...' of 1980. He was a member of the Editorial Board from its inception (as a compact body of six) in 1951 to his retirement; his chairmanship set standards which still in some measure, I hope, persist.

A fuller account of his career than is here possible will be found in the number, BSOAS, xxxvi, 2, which was dedicated to him as a Festschrift; and in the obituary which is to appear in the Proceedings of the British Academy.

Those who knew Professor Simon will be aware of the qualities that are not set down in the record : of the pains he took in encouraging and bringing on the work of younger scholars; of the diffidence which tempered his own principled scholarly eminence; of his profound courtesy and kindness. He will be long remembered with gratitude.

H. L. SHORTo 